\title{
Finite Element Method Application to Determine Appropriate Splitting Parameters for Dimensional Stone Quarries
}

\author{
Pham VAN VIET ${ }^{1, *)}$, Nguyen ANH TUAN ${ }^{1)}$, Pham VAN HOA ${ }^{1)}$
}

\author{
${ }^{1)}$ Hanoi University of Mining and Geology, Hanoi, Vietnam; email: phamvanviet@humg.edu.vn; nguyenanhtuan@humg.edu.vn; \\ phamvanhoa@humg.edu.vn
}

http://doi.org/10.29227/IM-2020-02-13

Submission date: 06-03-2020 | Review date: 22-09-2020

\section{Abstract}

In dimension stone extraction, there have existed many block cutting techniques from intact rock or from a large block to smaller blocks such as disc sawing, chainsawing, diamond wire sawing and splitting techniques, one of which still has recently been used with the other modern methods is splitting techniques. The usage of the splitting methods has still based on the practical experience of mining workers on calculating the spacing of two holes in the co-planar line, resulting in increasing the roughness of the cutting face. The paper studies a relationship between beating force and two-hole spacing based on rock mass properties of dimension stone in order to find proper splitting parameters. The paper deploys the Finite Element Method (FEM) with computer simulation in $2 D$ using Phase 2 software. From input data including rock mechanics (unit density, Young's modulus, Poisson's rate), compressive pressure on the hole wall due to the force, the spacing, the simulation represents stress and displacement distributions along the two adjacent holes. A regression function for a relationship between the pressure and the spacing is established with the results of stress distribution along the two adjacent holes, compared to uniaxial tensile strength through running the software, which leads to making suggestions to appropriate splitting parameters.

Keywords: dimension stone, splitting techniques, simulation, finite element method, FEM

\section{Introduction}

Dimension stone is a natural stone collection used in construction and monumental applications with the aims of structure or decoration (Merke, 2000). Differing from other mineral commodities, the value of which depends mainly on their physical properties, dimension stone quality is firstly shown in its appearance and secondly in its rectangular shape (Mining \& 2004, n.d.). The appearance of stone to satisfy the applications is identified with a set of criteria, including colour, texture and the presence or absence of discontinuities (Carvalho et al., 2008). Particularly, Luodes et al. suggested three main criteria which are usually applied for dimension stone evaluation, namely the appearance, the soundness of the deposit and the market demand (Luodes et al., 2000).

Dimension stone exploitation is splitting or cutting the stone into separate smaller pieces to achieve the final desired block size. The range for utilizing the mining method in the extraction of dimension stone is relatively large, from simple and low technology method to some quite technologically advanced methods. Firstly, splitting techniques, the oldest of techniques used in dimension stone exploitation drilling of a series of small-diameter co-planar holes, include plugs and feathers, mechanical splitting, expansive mortar and explosive splitting. Actually, plugs and feathers technique is that two shape steel feathers (half-round steel strips) with steel plug or wedge between them is attached into co-planar holes, causing a line of splitting along the co-planar holes from a lateral force driven with a hammer. Similarly, mechanical splitting has the same principle as plugs and feathers, but force hitting a steel plug between two feathers is replaced with hydraulic cylinder. Secondly, cutting techniques, including diamond wire saw- ing, chainsawing, disc sawing, appears later than the splitting techniques, but they could improve more disadvantage the one encountered in dimension stone mining operation, such as the productivity and the recovery on the dimension stone shape.

The mining methods applied in a dimension stone quarry depend strongly on the geology of the deposit. Particularly, boulder formations will be cut by means of splitting methods, while solid formations will be necessary to choose a method combination. This appears because the advanced method is needed to divide solid formation into large blocks so that the cutting expense could reduce to the minimum and splitting methods could be carried out to split the large blocks into small blocks that could be divided by the defects within the stone in order to maximize the recovery and value of saleable blocks (Ashmole \& Motloung, 2008).

In actual dimension stone extraction of Vietnam, the recovery rate of saleable blocks is quite low, leading to high production cost per a product. The reason for this is that joint sets in the stone have not exactly been identified, although the advanced cutting techniques have already been applied in the quarries, such as diamond wire sawing and disc sawing, helping to increase high productivity. Therefore, to decrease in the production cost and the effect of joints on the recovery rate, the method combination between splitting methods (plugs and feathers, mechanical splitting) and cutting methods (diamond wire sawing, disc sawing) is deployed. Moreover, the application of the splitting methods has still based on miner's experience to calculate driving forces to co-planar holes and spacings between the holes. Therefore, it is necessary to find the way to establish a relationship between the 


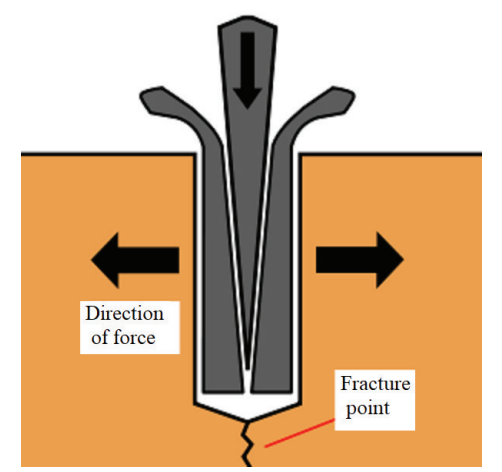

Fig. 1. Principle of splitting technique (Source:Internet)

Rys. 1. Zasada techniki rozłupywania (źródło: Internet)

Tab. 1. The positive relation between drill hole diameter and the length of plugs and feathers Tab. 1. Pozytywna zależność między średnicą wierconego otworu a długością kołków

\begin{tabular}{|c|c|c|}
\hline No & Drill hole diameter, $\mathbf{m m}$ & Length of plugs and feathers, $\mathbf{m m}$ \\
\hline 1 & 14 & 125 \\
\hline 2 & 16 & 125 \\
\hline 3 & 20 & 190 \\
\hline 4 & 24 & 190 \\
\hline 5 & 32 & 270 \\
\hline 6 & 34 & 290 \\
\hline 7 & 38 & 400 \\
\hline
\end{tabular}

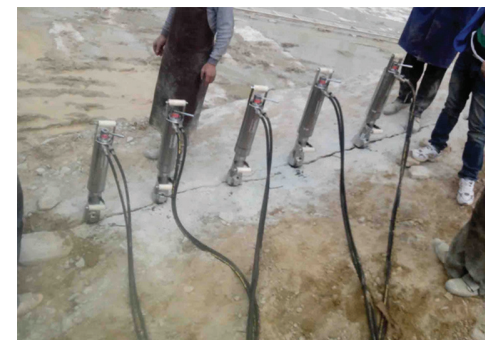

Fig. 2. Beating force supplied by compressive air energy (Source: Internet)

Rys. 2. Siła uderzenia dostarczana przez energię sprężonego powietrza (Źródło: Internet)

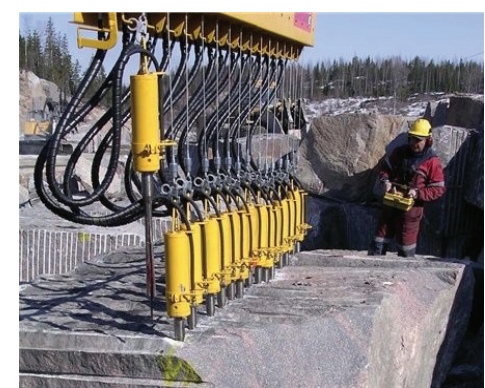

Fig. 3. Beating force supplied by hydraulic energy (Source: Internet)

Rys. 3. Siła uderzenia dostarczana przez energię hydrauliczną (Źródło: Internet)

spacing of co-planar holes and the force (or pressure on the hole walls) so that when the spacing is known, the pressure could be computed with how much the maximum pressure could ensure that no crack will appear around the holes and how much the minimum pressure could ensure that a co-planar crack will appear along the two adjacent holes.

In recent years, there have been more studies about splitting methods for dimension stone quarries. The optimum spacing for splitting dimension stone by blasting energy was given based on the blasting energy in each co-planar hole (Sanchidrian et al., 2000). The force analysis of hydraulic stone splitter was interested in improving the wedge components of the machine using ANSYS software where the stress and the deformation distribution analysis of each part of the splitting device was taken place (Shafer, 2010). Similarly, the working of wedge assembly components of mine splitter was upgraded studying wedge assembly's element content by EDS, and through different heat treatments (Shi et al., 2020). A plastic substance and specific factors influencing energy input were considered to physically simulate natural stone block cutting under consideration on impact load application sequence, the pattern of drill holes and sizes of cut stone blocks (Tambovtsev, 2015). The comparison of three splitting techniques, consisting of wedges and feathers, expansive cement, and 


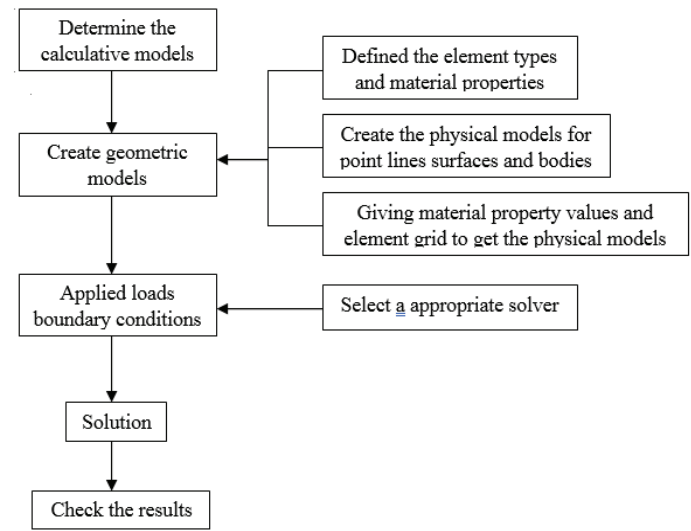

Fig. 4. Flow chart of finite element simulation by Phase2 (Rocscience Inc, 2005) Rys. 4. Schemat blokowy symulacji elementów skończonych w fazie 2 (Rocscience Inc, 2005)

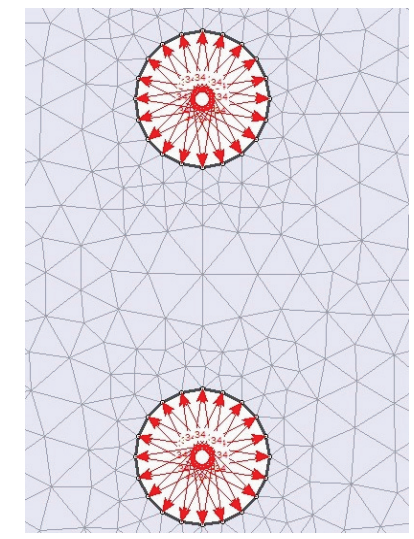

Fig. 5. Nodes was meshed and the pressure was assigned

Rys. 5. Węzły zostały łączone i przypisane ciśnienie

controlled blasting methods, was studied based on physical and mechanical rock property, such as core recovery, uniaxial compressive strength, Brazilian tensile strength, dynamic Young's modulus quality and P-wave velocity to choose the most proper technique for the extraction of rock salt block (Majeed et al., 2019). In general, the studies above considered about splitting methods in dimension stone quarries, such as blasting methods and wedges and feathers, expansive cement, but the way to study these techniques was still based on cumulated experiences. There was just a study applying the Finite Element Method (FEM) with ANSYS software to design wedge components. As a result, the paper represents how to comprehensively complete splitting techniques with plugs and feathers, mechanical splitting adopting computer simulation for stress and displacement distribution analysis along with the two adjacent wedge - inserted drill holes. The application of the FEM helps to find a relationship between the pressure on the hole wall and the spacing. When the spacing is constant, the pressure will change from the minimum to the maximum value so that a co-planar crack will be appeared along two adjacent holes and no crack will be appeared around the holes.

\section{Determine Appropriate Splitting Parameters for Dimen- sional Stone Quarries}

Splitting technique, including plugs and feathers, mechanical splitting, used to split dimension stone, consists of two mutual relationship stages. The first stage is co-planar holes are drilled in the vertical or horizontal desired direction. Mine splitters or plugs and feathers are, then, inserted into the drill holes by hydraulic energy or manual labour force. Dimension stone is divided into standard blocks with $20 \mathrm{~mm}$ to $42 \mathrm{~mm}$ drill hole diameter depending on the size of plugs and feathers (Fig. 1). The positive correlation between drill hole diameter and the length of plugs and feathers is shown in Tab.1.

Moreover, the length of the drill hole in the splitting methods is from about $8 \mathrm{~cm}$ to $10 \mathrm{~cm}$, but the length, depending on fracture condition in the stone, should be deepened. Another parameter, distance between two adjacent holes in the co-planar line, is also important in the method. This figure is heavily dependent on wedge-beating force. In the past, when stone splitting was carried out by manual labour force created due to beating hummer, the spacing chosen depended on the miner's experience, from $5 \mathrm{~cm}$ to $10 \mathrm{~cm}$. Nowadays, the beating force could be generated from compressive air energy or hydraulic energy, so the spacing will be significantly expanded (Fig. 2 and Fig. 3).

The purpose of the splitting methods is creating a crack plane connecting between two adjacent holes. The plane appeared depends on a relationship between two adjacent holes and holes of wall pressure. It is exact that the shorter the spacing is, the crack will be created smoothly, but the cost will increase significantly. Consequently, determining proper 


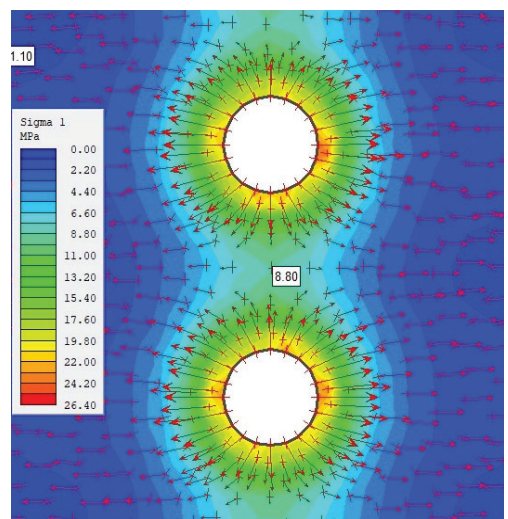

Fig. 6. Stress distribution of the two adjacent wedge holes Rys. 6. Rozkład naprężeń w dwóch sąsiednich otworach klinowych

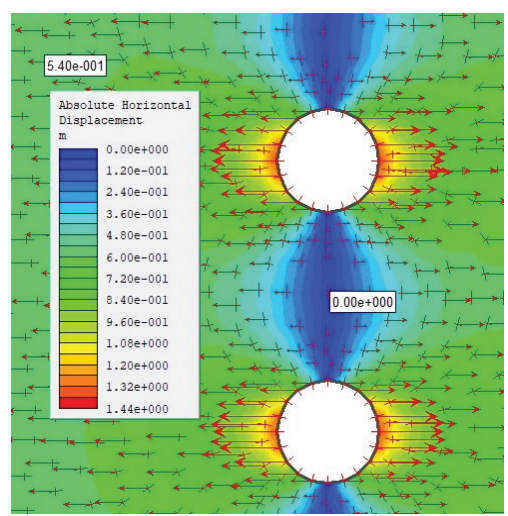

Fig. 7. Displacement distribution of the two adjacent wedge holes Rys. 7. Rozkład przemieszczeń dwóch sąsiednich otworów klinowych

splitting parameters for dimension stone is that the spacing is significantly important to ensure a specific spacing with the installed pressure changing from the minimum to the maximum so that a crack formed along to two adjacent holes to separates block stone must keep the smoothest as possible, which will bring the production cost down to the minimum. This could be done by beginning from stress and deformation distribution created from the pressure of two adjacent drill holes. When studying this stress area see that tensile stress area will be created in the direction at a right angle to the line connecting two adjacent holes, which results in the appearance of a crack between the two holes. In the other hand, the tensile stress area must exceed the uniaxial tensile strength of stone, as well as the compressive stress on hole walls, must be not exceeded the uniaxial compressive strength.

$$
\begin{aligned}
& \sigma \Sigma \geq[\sigma] \mathrm{k} \\
& \sigma \text { đ } \leq[\sigma] \mathrm{n}
\end{aligned}
$$

where: $\sigma \Sigma$ is stress area between two adjacent holes, $\mathrm{kN} /$ $\mathrm{m}^{2}$; $\sigma \mathrm{d}$ is stress area surrounding drill hole generated due to beating force on hole walls, $\mathrm{kN} / \mathrm{m}^{2} ;[\sigma] \mathrm{k}$ represents a tensile strength of stone, $\mathrm{kN} / \mathrm{m}^{2} ;[\sigma] \mathrm{n}$ represents compressive strength of stone, $\mathrm{kN} / \mathrm{m}^{2}$;

This is a complicate issue when computing stress development in the rock environment because the influences of rock mechanic properties are considered to stress distribution and computing volume is massive. As a result, the Finite Element
Method (FEM) is deployed to analyze stress and deformation distribution in stone under consideration on the wedge-beating force between two adjacent holes. The numerical method has several characteristics shown below (Koutromanos, 2018):

\section{Displacement Interpolation Function Selection:}

The displacement, strain and stress of any node within the element is displayed using node displacement, and we can suggest the displacement assumption of any node point within the element is a sort of simple function of coordinates, called displacement function (Fig. 5)

$$
\{\mathrm{f}\} \mathrm{e}=[\mathrm{N}]\{\delta\} \mathrm{e}
$$

Where: \{f\}e shows the displacement column matrix of any node within the element; $\{\delta\}$ e depicts the nodal point displacement column matrix; $[\mathrm{N}]$ is the shape function matrix.

\section{Element analysis}

The geometric elasticity equations were applied to express with the nodal point displacement, and the element strain can be achieved and expressed by:

$\{\varepsilon\}=[B]\{\delta\} \mathrm{e}$

Where: $\{\varepsilon\}$ shows strain column matrix of any nodal point within the element and $[\mathrm{B}]$ is the geometric matrix.

The element stress can be performed with the help of 
Tab 2. Physical and mechanical properties of gabrodiorit stone

Tab 2. Właściwości fizyczne i mechaniczne kamienia gabrodiorit

\begin{tabular}{|c|l|c|c|}
\hline No & \multicolumn{1}{|c|}{ Content } & Unit & Value \\
\hline 1 & Moisture & $\%$ & 0.05 \\
\hline 2 & Water absorption & $\%$ & 0.24 \\
\hline 3 & Bulk density & $\mathrm{g} / \mathrm{cm} 3$ & 2.699 \\
\hline 4 & Dry uniaxial compressive strength & $\mathrm{MPa}$ & 87.8 \\
\hline 5 & Saturated uniaxial compressive strength & $\mathrm{MPa}$ & 83.4 \\
\hline 6 & Uniaxial tensile strength & $\mathrm{Mpa}$ & 8.07 \\
\hline 7 & Softening coefficient & & 0.94 \\
\hline 8 & Young's Modulus & $\mathrm{Mpa}$ & 0.673 \\
\hline 9 & Deformation Modulus & $\mathrm{Mpa}$ & 0.64 \\
\hline 10 & Cohesion & Mpa & 8.9 \\
\hline 11 & Internal friction angle & degree & 40033 \\
\hline
\end{tabular}

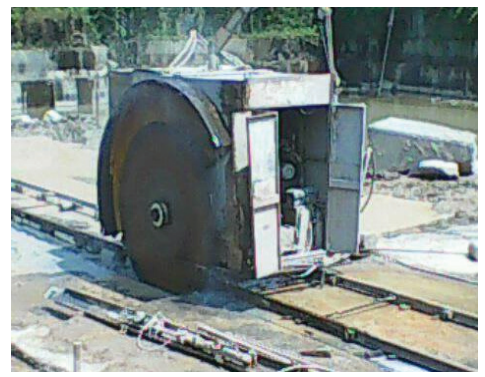

Fig. 8. Disc sawing machine operation at Chu Que dimension stone quarry in Thua Thien Hue Province of Vietnam Rys. 8. Piła tarczowa w kamieniołomie Chu Que w prowincji Thua Thien Hue w Wietnamie
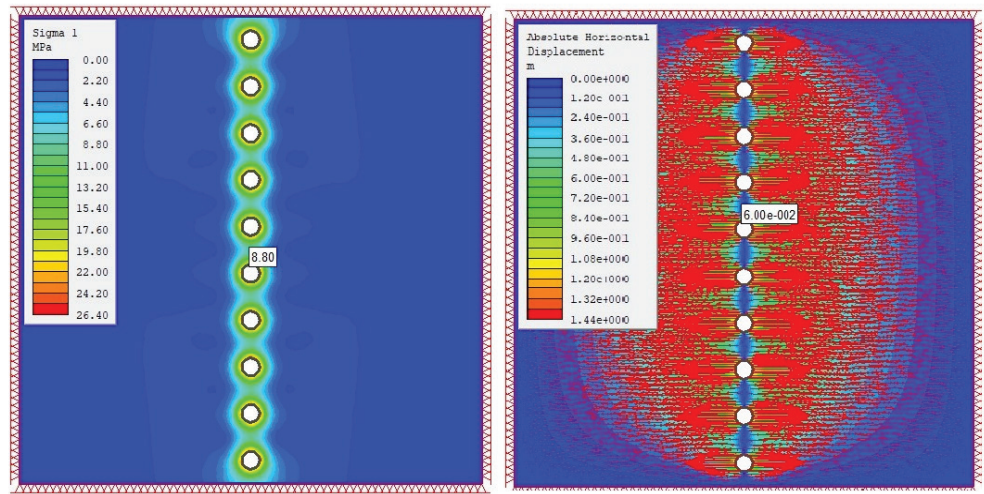

Fig. 9. Stress and displacement distribution with the minimum pressure of $34 \mathrm{Mpa}$ to form a splitting plane between the two adjacent holes when the spacing of $0.1 \mathrm{~m}$

Rys. 9. Rozkład naprężeń i przemieszczeń przy minimalnym ciśnieniu 34 Mpa w celu utworzenia płaszczyzny podziału między dwoma sąsiednimi otworami przy rozstawie $0,1 \mathrm{~m}$

physics equations in the form of nodal displacement in Fig.6.

$$
\{\sigma\}=[\mathrm{D}]\{\mathrm{B}\}\{\delta\} \mathrm{e}=[\mathrm{S}]\{\delta\} \mathrm{e}
$$

Where: $\{\sigma\}$ is the stress matrix of internal element node; $[D]$ is the elastic matrix; [S] is the stress matrix of an element.

A relationship function between the external force sizes that influence on the nodal point and the displacement of the node was established using virtual work equations. Consequently, the stiffness equations can be obtained in order to reach the stiffness matrix of the element.

$$
\begin{aligned}
& {[\mathrm{P}] \mathrm{e}=[\mathrm{K}] \mathrm{e}\{\delta\} \mathrm{e}} \\
& {[\mathrm{K}] \mathrm{e}=\int \mathrm{v}[\mathrm{B}] \mathrm{T}[\mathrm{D}][\mathrm{B}] \mathrm{dv}}
\end{aligned}
$$

Where: $[\mathrm{K}] \mathrm{e}$ is the stiffness matrix of element

\section{Overall analysis}

All element stiffness equations were collected to create balance equation of the entire structure. So the overall stiffness matrix was formed:

$$
[\mathrm{K}]\{\delta\}=\{\mathrm{P}\}
$$

Where: $[\mathrm{K}]$ is the stiffness matrix of entire structure; $\{\delta\}$ is the displacement column matrix of all structural nodes; $\{\mathrm{P}\}$ is the column matrix of equivalent node load for the whole structure.

\section{The simulation Process of Finite Element Software Phase2}

Phase 2 software has a robust two-dimensional modelling ability and material modelling techniques. Based on the topdown or bottom-up approach and Boolean operations, coordinate transformation and other ways, Phase2 software can 

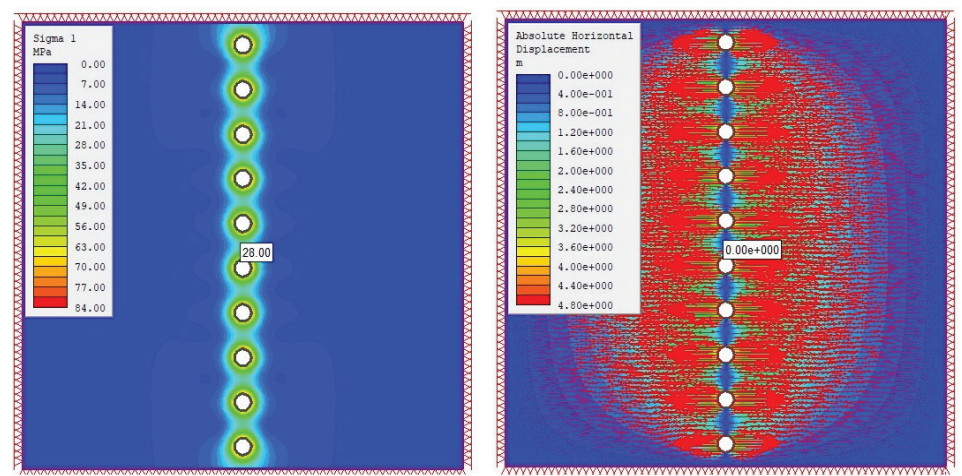

Fig. 10. The stress and displacement distribution with the maximum pressure of $105 \mathrm{Mpa}$ to form a splitting plane between the two adjacent holes when the spacing of $0.10 \mathrm{~m}$

Rys. 10. Rozkład naprężeń i przemieszczeń przy maksymalnym ciśnieniu 105 Mpa w celu utworzenia płaszczyzny podziału między dwoma sąsiednimi otworami przy rozstawie $0,10 \mathrm{~m}$
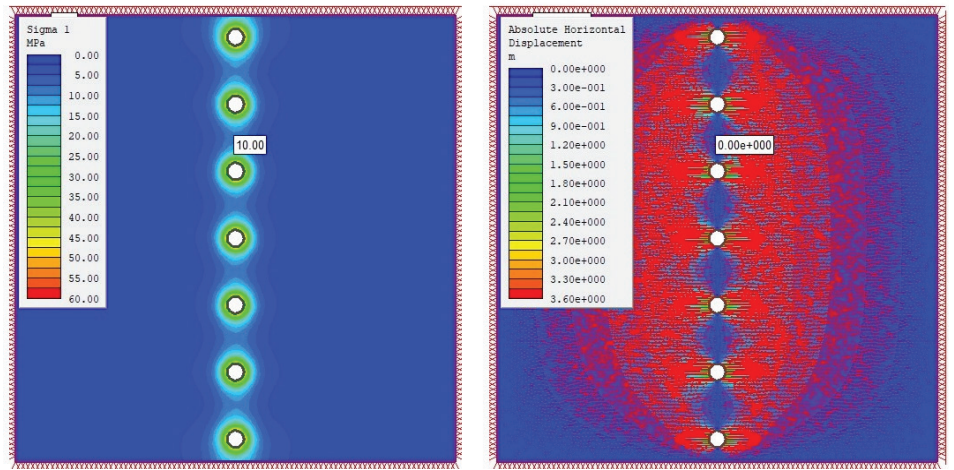

Fig. 11. The stress and displacement distribution with the minimum pressure of $66 \mathrm{Mpa}$ to form a splitting plane between the two adjacent holes when the spacing of $0.15 \mathrm{~m}$

Rys .11. Rozkład naprężeń i przemieszczeń przy minimalnym ciśnieniu $66 \mathrm{Mpa} \mathrm{w} \mathrm{celu} \mathrm{utworzenia} \mathrm{płaszczyzny} \mathrm{podziału} \mathrm{między} \mathrm{dwoma} \mathrm{sąsiednimi}$ otworami przy rozstawie $0,15 \mathrm{~m}$
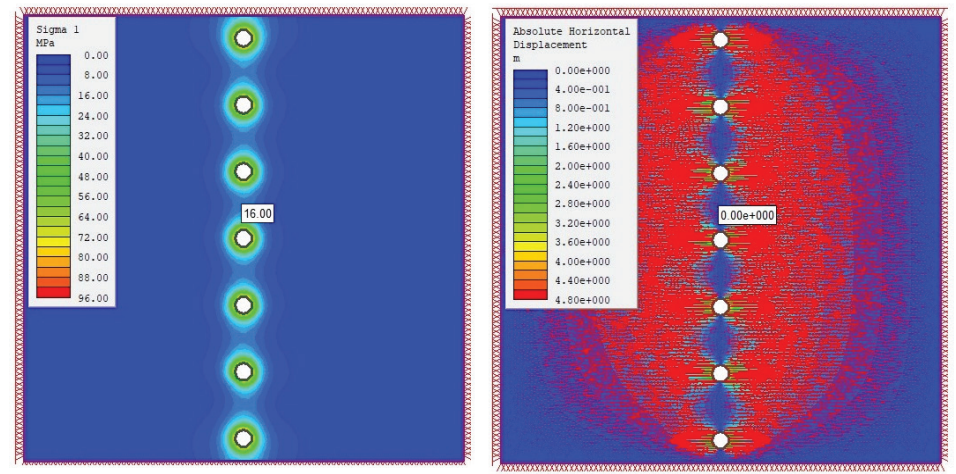

Fig. 12. Stress and displacement distribution with the maximum pressure of $105 \mathrm{Mpa}$ to form a splitting plane between the two adjacent holes when the spacing of $0.15 \mathrm{~m}$

Rys. 12. Rozkład naprężeń i przemieszczeń przy maksymalnym ciśnieniu $105 \mathrm{Mpa} \mathrm{w}$ celu utworzenia płaszczyzny podziału między dwoma sąsiednimi otworami przy rozstawie $0,15 \mathrm{~m}$

build truly reflect the two-dimensional geometric model of the complex project structure (Rocscience Inc, 2005).

From the software Phase2, steps need to be carried out to establish appropriate splitting parameters:

Step 1: Set up a model by drawing a dimension stone model and inserting a drilling hole with specific spacing.

Step 2: The material properties of dimension stone is assigned to the model.

Step 3: Set up a continuous model by meshing nodes

Step 4: Pressure on the wall of the holes is assigned (Fig. 5)
Step 5: The model is run with the change of pressure inputs

With a specific spacing of two adjacent holes, the pressure is changed. When the model is run, a stress distribution along to the holes will appear. Through the model, a stress area formed in this area is the tensile stress area (Fig. 6). Therefore, major stress in this area exceeds the uniaxial tensile strength of stone, leading to displacement along the two holes will be happened (Fig. 7). This determines a minimum pressure to form a crack between the two adjacent holes. When the 
Tab. 3. Minimum pressures and maximum pressures on the hole walls with the spacing of $0.1 \mathrm{~m}, 0.15 \mathrm{~m}$ and $0.2 \mathrm{~m}$ Tab. 3. Naciski minimalne i maksymalne na ścianki otworów w rozstawie $0,1 \mathrm{~m}, 0,15 \mathrm{mi}$ 0,2 m

\begin{tabular}{|c|c|c|c|}
\hline No & Spacing, $\mathbf{m}$ & $\begin{array}{c}\text { Minimum } \\
\text { pressure, } \\
\text { Mpa }\end{array}$ & $\begin{array}{c}\text { Maximum } \\
\text { pressure, } \\
\text { Mpa }\end{array}$ \\
\hline 1 & 0.1 & 34 & 105 \\
\hline 2 & 0.15 & 66 & 105 \\
\hline 3 & 0.2 & 105 & 105 \\
\hline
\end{tabular}

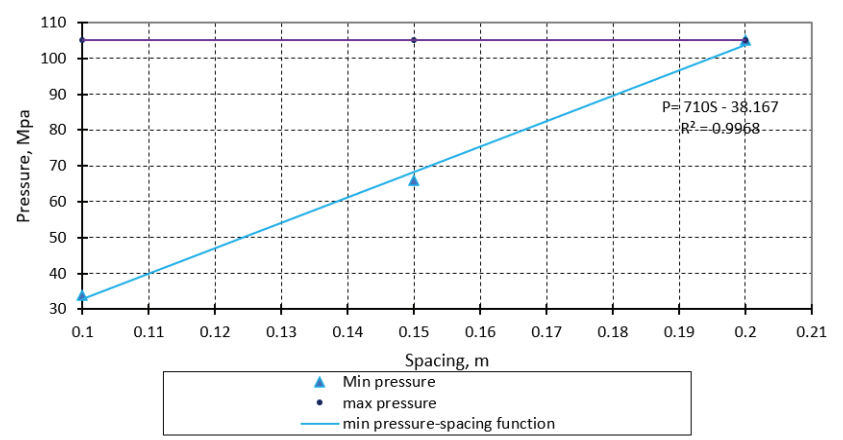

Fig. 13. A relationship between the pressure and the spacing shown via a change from min pressure to max pressure constant with spacing increment Rys. 13. Zależność między ciśnieniem a rozstawem pokazanym jako zmiana od minimalnego ciśnienia do maksymalnego stałego ciśnienia wraz ze wzrostem odstępu

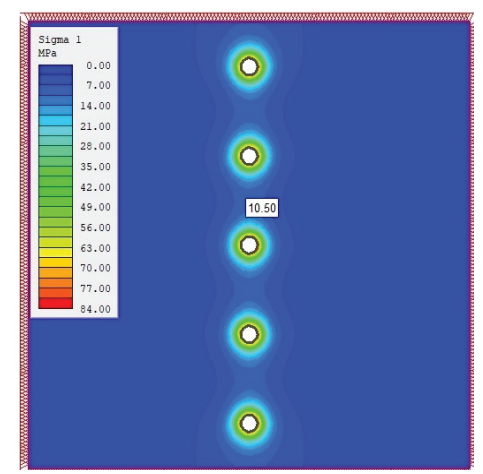

Fig. 14. With the spacing of $0.2 \mathrm{~m}$, a minimum pressure equals to a maximum pressure to not appear more unwanted cracks in splitted blocks Rys. 14. Przy rozstawie 0,2 m minimalne ciśnienie równe jest maksymalnemu ciśnieniu, aby nie pojawiać się więcej niepożądanych pęknięć w rozłupanych blokach

pressure modified changes to a specific value, it is indicated that major stress area surrounding the holes obtains a uniaxial compressive strength of stone (if major stress exceeds this value, cracks surrounding the holes will appear. Therefore, through building a model with the software Phase2, a range of pressure on the hole walls will be found with such a specific spacing.

\section{Case Study at Chu Que dimensional stone quarry in Viet-} nam

Chu Que dimensional stone quarry in Thua Thien Hue Province extracted grabrodiorit stone, black colour mixing with white and grey-white spots. Its structure is fine crystalline pieces, some of which are grey-colour pieces distributed uniformly. Moreover, the rock mechanical properties were presented in tab. 2 .

When cutting dimensional stone, the quarry combined three cutting methods, including disc sawing, diamond wire sawing, splitting. Firstly, the disc sawing machine was run on the track in a parallel line with the spacing of $1.04 \mathrm{~m}$, and its deep cutting was $1.35 \mathrm{~m}$ (Fig.7). After that, the diamond wire saw was used to cut the bottom plane. This was done by horizontally drilling $32 \mathrm{~mm}$-diameter holes to make a close diamond wire loop over the flywheel. Finally, splitting techniques were implemented after the two methods above to split into the standard blocks with their size of $1.7 \mathrm{~m} \mathrm{x} 1.04 \mathrm{~m} \times 1.35 \mathrm{~m}$.

In stone splitting operation of the quarry, splitting holes with the depth of about $0.15 \mathrm{~m}$, the various spacings from 0.1 to $0.2 \mathrm{~m}$ and the diameter of $0.038 \mathrm{~m}$ were drilled with handhold drilling machine. Due to the spacing changing from 0.1 to $0.2 \mathrm{~m}$, the quarry will encounter more difficulty in calculating how much the beating force becomes proper to create a straight splitting plane between the two adjacent holes in stone as well as to reduce to the minimum of undesired crack appearance in splitted stones. Therefore, through the simulation, a relationship between the pressure and the spacing will be established. 


\section{Results for Chu Que dimension stone quarry}

Through the simulation with the spacing of $0.10 \mathrm{~m}$, the result showed that to form a stress distribution area of value sufficiency more than the uniaxial tensile strength of stone on an imaginary plane between two wedged holes, the minimum pressure on their walls would be $34 \mathrm{Mpa}$ (Fig. 9). Moreover, the maximum pressure of 105 on the walls would be defined with the compressive stress distribution area around the holes to not exceed the uniaxial compressive strength of stone (Fig. 10). Similarly, the minimum pressure and the maximum pressure also were identified with the spacing of $0.15 \mathrm{~m}$ in Fig. 11 and Fig. 12. The results showed for the spacings of $0.1 \mathrm{~m}, 0.15 \mathrm{~m}$ and $0.2 \mathrm{~m}$ given in Tab. 3 and Fig 13 . The figure showed that when the spacing increases, the minimum pressure also rises with the function, but the maximum pressure always keeps in a constant of $105 \mathrm{Mpa}$. However, the spacing of about $0.2 \mathrm{~m}$ will be a limit to create a splitting plane because the minimum pressure in the hole creates a stress distribution area of value sufficiency more than the uniaxial tensile strength of stone on an imaginary plane between two wedged holes as well as the pressure on the walls also generates a compressive stress distribution area around the holes to just equal to the uniaxial compressive strength of stone. If overtaking the limit, it will appear more unwanted cracks in split blocks in Fig .14.

\section{Conclusions}

Although dimensional stone cutting techniques have been modernly invested, such as diamond wire sawing, disc sawing, chainsawing, splitting methods in the quarries have still been existed due to its combination with the modern methods to decrease production cost. However, it existed for ages; almost splitting parameters have still been based on the miner's experience. The study establishes how to comprehensive, complete splitting parameters based on finite element simulation, Phase 2 software. The paper suggests some detail conclusions: The positive correlation between the force (pressure) and the spacing is shown, so when knowing the spacing, the force will be computed from the chart; The shorter the spacing is, a splitting plane in co-planar line will be smoother, but the splitting cost is high; Proper spacing range for each dimension stone is given based on the consideration of the uniaxial tensile strength and the uniaxial compressive strength.

Moreover, the influence of hole length and existed joints on splitting techniques will be studied as well as the $3 \mathrm{D}$ simulation will be necessary to develop to deal with this impact. 


\section{Literatura - References}

1. Ashmole, I., \& Motloung, M. (2008). DIMENSION STONE : THE LATEST TRENDS IN EXPLORATION AND PRODUCTION TECHNOlOGY Greenstone Marble and Granite ( Pty ) Ltd Finstone (SA ) ( Pty ) Ltd. 35-70.

2. Carvalho, J. F., Henriques, P., Falé, P., \& Luís, G. (2008). Decision criteria for the exploration of ornamental-stone deposits: Application to the marbles of the Portuguese Estremoz Anticline. International Journal of Rock Mechanics and Mining Sciences, 45(8), 1306-1319. https://doi.org/10.1016/j.ijrmms.2008.01.005

3. Koutromanos, I. (2018). Fundamentals of Finite Element Analysis: Linear Finite Element Analysis. John Wiley \& Sons.

4. Luodes, H., Selonen, O., \& Pääkkönen, K. (2000). Evaluation of dimension stone in gneissic rocks -- A case history from Southern Finland. Engineering Geology, 58(2), 209-223. https://doi.org/10.1016/S0013-7952(00)00059-4

5. Majeed, Y., Emad, M. Z., Rehman, G., \& Arshad, M. (2019). Block Extraction of Himalayan Rock Salt by Applying Conventional Dimension Stone Quarrying Techniques. 55(4), 610-625. https://doi.org/10.1134/ S1062739119045965

6. Merke, G. (2000). Sustainable development in the natural stone industry. Roc Maquina, 56-58.

7. Mining, I. A.-S. S., \& 2004, U. (n.d.). Dimension stone: the small scale mining potential in South Africa.

8. Rocscience Inc. (2005). a two-dimensional finite element analysis program (Phase2 v6.0).

9. Sanchidrian, J. A., Garcia-Bermudez, P., \& Jimeno, C. L. (2000). Optimization of granite splitting by blasting using notched holes. Fragblast, 4(1), 1-11. https://doi.org/10.1080/13855140009408059

10. Shafer, S. L. (2010). Wedge components of the Hydraulic Stone Splitter. Anesthesia and Analgesia, 111(6), 1561. https://doi.org/10.1213/ANE.0b013e3182009a22

11. Shi, G., Huang, C., Liao, W., Li, J., \& Minxiong, X. (2020). Study of the influence of heat treatment process on the mechanical performance of wedge shaped components. IOP Conference Series: Materials Science and Engineering, 738(1). https://doi.org/10.1088/1757-899X/738/1/012021

12. Tambovtsev, P. N. (2015). Physical simulation of stone block cutting under impact action on plastic substance in drill hole. Journal of Mining Science, 51(1), 73-80. https://doi.org/10.1134/S106273911501010X

\section{Zastosowanie metody elementów skończonych do określania odpowiednich parametrów tupania w kamieniołomach kamieni blocznych}

W zakresie wydobywania złoża kamieni blocznych istniało wiele technik cięcia bloków, od nienaruszonej skały lub od dużych bloków do mniejszych bloków, takich jak piły tarczowe, piły łańcuchowe, piły diamentowe i techniki łupania, z których jedna jest ostatnio używana z druga nowoczesna metody to techniki dzielenia. Stosowanie metod tupania nadal opiera się na praktycznym doświadczeniu górników przy obliczaniu rozstawu dwóch otworów w linii współpłaszczyznowej, co skutkuje zwiększeniem chropowatości czoła skrawania. W artykule zbadano zależność między siła uderzenia a rozstawem dwóch otworów na podstawie właściwości górotworu kamieni blocznych $w$ celu znalezienia odpowiednich parametrów rozłupywania. W artykule zastosowano metodę elementów skończonych (MES) z symulacją komputerowa 2D przy użyciu oprogramowania Phase2. Na podstawie danych wejściowych obejmujacych mechanikę skat (gęstość jednostkowa, moduł Younga, współczynnik Poissona), ciśnienie ściskające na ściane otworu spowodowane siła, rozstaw, symulacja przedstawia rozkłady naprężeń i przemieszczeń wzdłuż dwóch sąsiednich otworów. Na podstawie wyników rozkładu naprężeń wzdłuż dwóch sąsiednich otworów, w porównaniu z jednoosiową wytrzymałością na rozciaganie po uruchomieniu oprogramowania, ustala się funkcję regresji zależności między ciśnieniem a rozstawem, co prowadzi do sugestii dotyczących odpowiednich parametrów rozłupywania.

Słowa kluczowe: kamienie bloczne, techniki łupania, symulacja, metoda elementów skończon 